Nig. J. Anim. Prod. 2017 44(1):222 - 226

(C) Nigerian Society for Animal Production

Nigerian Journal of Animal Production

\title{
Effect of varying energy and protein levels on carcass characteristics of helmet Guinea fowls in the tropics
}

Odukwe, C. N., Ukachukwu, S. N., Onunkwo, D. N. and Oke, U. K.

${ }^{1}$ Department of Animal Nutrition and Forage Science,

College of Animal Science and Animal Production,

Michael Okpara University of Agriculture, Umudike, Umuahia,

Abstract Abia State, Nigeria.

The effect of energy and protein and their interaction on carcass characteristics of helmet Guine a fowls in the tropics was investigated using one hundred and thirty-five Guinea fowls. The experiment which lasted for 5 weeks involved a $3 * 3$ factorial in completely randomized design. The birds were randomly assigned to experimental diets containing three energy levels: 2500, 2600 and $2700 \mathrm{kcal} / \mathrm{kg}$ denoted as $E_{1}, E_{2}$ and $E_{3,}$ respectively and three protein levels: $15 \%, 16 \%$ and $17 \% \mathrm{CP}$ denoted as $P_{1}, P_{2}$ and $P_{3}$, respectively. The factorial design involved nine treatment combinations. The birds were allocated to each diet and were replicated three times to contain five birds per replicate and 15 birds per treatment. The result revealed significant $(P<0.05)$ differences in the main effects of protein on dressed weight, thigh weight and breast weight. The $17 \%$ CP recorded the most significant values for dressed weight (689.44 g) and breast weight (24.89g). The varying energy levels also affected significantly $(P<0.05)$ the dressed weight, thigh weight, wing weight, breast weight, back weight and gizzard weight of the birds. The $2600 \mathrm{kcal} / \mathrm{kg}$ recorded the highest dressed weight (717.22 g) compared to the other energy levels. However, the $2700 \mathrm{kcal} / \mathrm{kg}$ recorded the most significant values in thigh, wing, breast, back and gizzard weights. The interaction effect of protein $x$ energy levels revealed significant $(P<0.05)$ effects on live weight, wing weight, breast weight, back weight and gizzard weight of the Guinea fowls. The findings from this experiment conclude that diet of Helmeted Guinea fowl containing $15 \% \mathrm{CP}$ and $2700 \mathrm{kcal} / \mathrm{kg}$ $M E$ gave the best carcass performance.

Keywords: Energy, protein, carcass characteristics, helmet Guinea fowls

\section{Introduction}

Guinea fowl production could be more efficient for meat production compared to domesticated fowls as their feed cost per kg edible parts is less than that of the fowls (Veicman, 1970). When compared to local chickens, Guinea fowl has numerous advantages are numerous. These advantages include low production costs, premium quality meat, greater capacity to scavenge for insects and grains, better ability to protect itself against predators and resistance to common poultry diseases (Microlivesstock, 1991). Guinea fowl production provides one of the best alternatives for the rural populace to access meat and eggs as well as potential for revenue generation through sales of live fowl and eggs. However, Guinea fowls are kept for egg and meat production (Ajala et al., 1997; Magaga and Haule, 1998; Smith, 2001), and poultry farmers want birds that will maximize production at an economic rate and still maintain a market carcass value at the end of production. Nsoso et al. (2003; 2006) and Nahashon et al. (2007) noted that Guinea fowl showed consistent significant increase in body weight over time but are slow in growth rates compared to broilers which reach 1.5 to $2 \mathrm{~kg}$ in $6-8$ weeks. Ayorinde and Ayemi (1983) also reported that Guinea fowls tend to be slow in growth, weighing less than $1 \mathrm{~kg}$ at eight weeks of age. Ayorinde et al. (1988) 
reported that Guinea fowl has a characteristic low live weight compared to chicken. The objective of this study is to determine the optimum energy and protein levels for the best carcass characteristics of helmeted guinea fowls in the tropics

\section{Materials and methods}

One hundred and thirty-five Guinea fowls were used for this experiment. The birds were randomly assigned to experimental diets containing three energy levels: 2500 , 2600 and $2700 \mathrm{kcal} / \mathrm{kg}$ and three protein levels: $15 \%, 16 \%$ and $17 \% \mathrm{CP}$ in a $3 * 3$ factorial in a CRD. The birds were allocated to each diet and were replicated three times with five birds per replicate and 15 birds per treatment. Data collection was for five weeks. The carcass quality of the Guinea

fowl was determined when the birds were eight weeks of age. It was carried out in the morning hours before the birds were fed. Two Guinea fowls were selected at random from each replicate, weighed individually, killed by cutting the neck close to the head, and allowed to bleed completely. Scalding was done in hot water and the feathers plucked off by hand individually. Evisceration was done with a very sharp knife and entire gut contents (organ and intestine) carefully removed and weighed immediately. The organs were weighed with a sensitive weighing (Acculab) scale. Data collected were subjected to analysis of variance (ANOVA) and significant means were separated using Duncan's Multiple Range F-test (Duncan, 1955).

\section{Results and Discussion}

Table 1: Effect of varying protein levels on carcass characteristics of helmet guinea fowls

\begin{tabular}{lcccr}
\hline Parameters & \multicolumn{3}{c}{ Crude protein level } & SEM \\
\cline { 2 - 4 } & $\mathbf{1 5 \%} \mathbf{C P}$ & $\mathbf{1 6 \%} \mathbf{C P}$ & $\mathbf{1 7 \%} \mathbf{C P}$ & 0.02 \\
\hline Live weight $(\mathrm{kg} / \mathrm{b})$ & 1.28 & 1.29 & 1.34 & 8.70 \\
Dressed weight $(\mathrm{g} / \mathrm{b})$ & $672.22^{\mathrm{b}}$ & $666.67^{\mathrm{c}}$ & $689.44^{\mathrm{a}}$ & 0.96 \\
Thigh weight $(\mathrm{g} / \mathrm{b})$ & $11.81^{\mathrm{b}}$ & $11.83^{\mathrm{a}}$ & $11.69^{\mathrm{c}}$ & 1.78 \\
Wing weight $(\mathrm{g} / \mathrm{b})$ & 20.12 & 19.75 & 20.08 & 0.40 \\
Neck weight $(\mathrm{g} / \mathrm{b})$ & 5.12 & 5.42 & 5.87 & 1.02 \\
Drumstick $(\mathrm{g} / \mathrm{b})$ & 11.69 & 11.70 & 11.51 & 2.43 \\
Breast weight $(\mathrm{g} / \mathrm{b})$ & $22.52^{\mathrm{ab}}$ & $20.97^{\mathrm{b}}$ & $24.89^{\mathrm{a}}$ & 2.10 \\
Back weight $(\mathrm{g} / \mathrm{b})$ & 16.83 & 15.69 & 17.27 & 27
\end{tabular}

a, b Means with different superscripts across the rows are significantly different at $\mathrm{P}<0.05$

Table 2: Effect of varying energy levels on carcass characteristics of helmet guinea fowls

\begin{tabular}{lcccc}
\hline Parameters & \multicolumn{3}{c}{ Energy levels (kcal/kg) } & SEM \\
\cline { 2 - 4 } & $\mathbf{2 5 0 0}$ & $\mathbf{2 6 0 0}$ & $\mathbf{2 7 0 0}$ & 0.01 \\
\hline Live weight $(\mathrm{kg} / \mathrm{b})$ & 1.27 & 1.33 & 1.39 & 5.00 \\
Dressed weight $(\mathrm{g} / \mathrm{b})$ & $633.33^{\mathrm{b}}$ & $677.78^{\mathrm{b}}$ & $717.22^{\mathrm{a}}$ & 1.01 \\
Thigh weight $(\mathrm{g} / \mathrm{b})$ & $12.07^{\mathrm{c}}$ & $10.85^{\mathrm{b}}$ & $12.41^{\mathrm{a}}$ & 1.63 \\
Wing weight $(\mathrm{g} / \mathrm{b})$ & $17.62^{\mathrm{b}}$ & $18.65^{\mathrm{b}}$ & $23.68^{\mathrm{a}}$ & 0.54 \\
Neck weight $(\mathrm{g} / \mathrm{b})$ & 4.92 & 5.36 & 6.14 & 1.02 \\
Drumstick $(\mathrm{g} / \mathrm{b})$ & 12.11 & 11.02 & 11.77 & 2.30 \\
Breast weight $(\mathrm{g} / \mathrm{b})$ & $20.45^{\mathrm{b}}$ & $20.50^{\mathrm{b}}$ & $27.43^{\mathrm{a}}$ & 1.03 \\
Back weight $(\mathrm{g} / \mathrm{b})$ & $14.56^{\mathrm{b}}$ & $15.94^{\text {ab }}$ & $19.29^{\mathrm{a}}$ & \\
\hline a b Means with different superscripts across the rows are significantly different at $\mathrm{P}<0.05$ &
\end{tabular}


Odukwe, Ukachukwu, Onunkwo and Oke

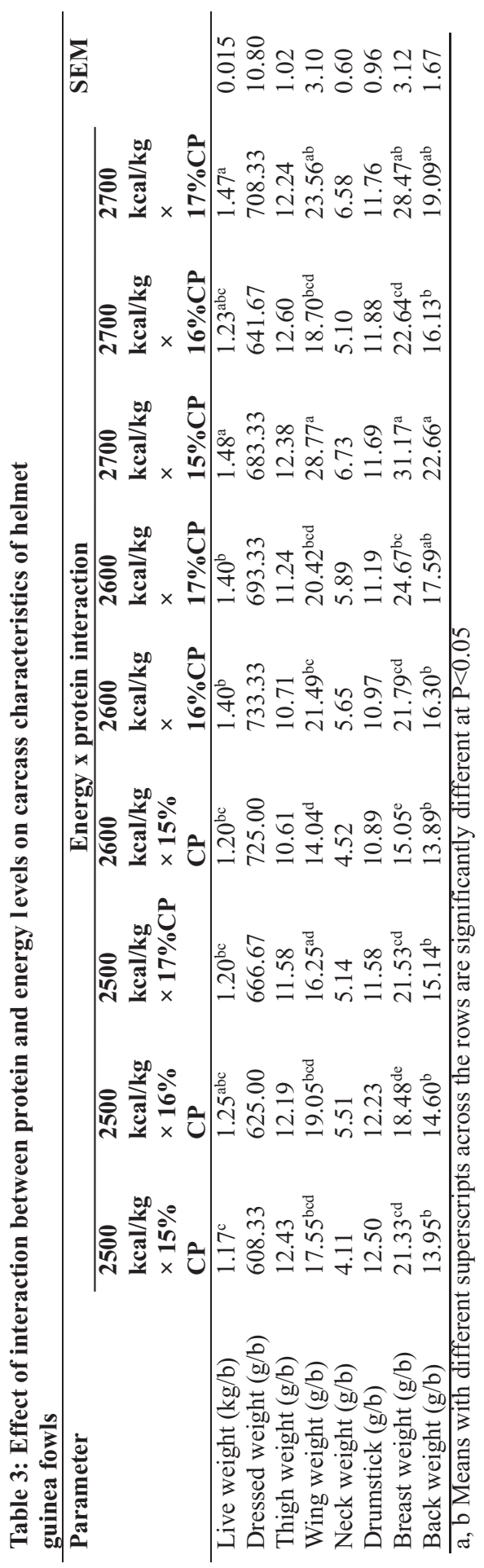


Table 1 shows the effect of varying protein levels on carcass characteristics of helmet Guinea fowls. Significant differences $(\mathrm{P}<0.05)$ were observed in dressed weight, thigh weight and breast weight. The $17 \%$ $\mathrm{CP}$ recorded the highest $(\mathrm{P}<0.05)$ dressed weight $689.44 \mathrm{~g} / \mathrm{b}$ and equally the highest breast weight $24.89 \mathrm{~g} / \mathrm{b}$. The $16 \% \mathrm{CP}$ recorded the highest $(\mathrm{P}<0.05)$ thigh weight $(11.83 \mathrm{~g} / \mathrm{b})$ whereas the $17 \% \mathrm{CP}$ diet obtained the least thigh weight $(11.69 \mathrm{~g} / \mathrm{b})$. Non-significant $(\mathrm{P}>0.05)$ differences were obtained due to varying protein levels on live weight, wing weight, neck weight, drumstick and back weight. This result indicates that the highest dietary protein level $(17 \% \quad \mathrm{CP})$ is required for best performance in dressed weight and breast weight. Table 2 shows the effect of varying energy levels on carcass characteristics of helmet Guinea fowls. Significant differences were observed in dressed weight, thigh weight, wing weight, breast weight, back weight and gizzard weight. No significant difference $(\mathrm{P}>0.05)$ was observed in live weight, neck weight and drumstick weight. The $2700 \mathrm{kcal} / \mathrm{kg}$ recorded was most significant in dressed weight, thigh weight, wing weight, breast weight and back weight. This result showed that $2700 \mathrm{kcal} / \mathrm{kg}$ energy level produced better carcass output compared to the lower energy levels of $2500 \mathrm{kcal} / \mathrm{kg}$ and 2600 $\mathrm{kcal} / \mathrm{kg}$. This result is in agreement with the report of Nahashon et al. (2005), which stated that dietary metabolizable energy composition has a major impact on body composition of Guinea fowl.

Table 3 shows the effect of interaction between protein and energy levels on carcass characteristics of helmet Guinea fowls. Significant interaction effects $(\mathrm{P}<$ 0.05 ) existed on live weight, wing weight, breast weight and back weight. Nonsignificant effect of interaction $(\mathrm{P}>0.05)$ was observed in dressed weight, thigh weight, neck weight and drumstick weight. The best interaction effect was obtained by the $2700 \mathrm{kcal} / \mathrm{kg} \times 15 \% \mathrm{CP}$ which recorded the most significant $(\mathrm{P}<0.05)$ values in live weight, wing weight, breast weight and back weight. This was closely followed by the $2700 \mathrm{kcal} / \mathrm{kg} \times 17 \% \mathrm{CP}$ which performed lower than the $2700 \mathrm{kcal} / \mathrm{kg} \times$ $15 \%$ CP (except in live weight where both were comparable) but higher than the other energy $\times$ protein groups. According to Adeyemi et al. (2008); Agunbiade et al. (2002) and Fanimo et al. (1996) the breast meat, drumstick and thigh are the most expensive commercial cuts of the chicken and also provide the greatest portions of edible meat in broilers. The result generally showed that improvement in thigh weight was separately dependent on individual effects of energy and protein levels rather than interaction which were not significant in this study. The breast weight was the only parameter that was affected significantly by the separate effects of protein, energy and their interaction effects. The live weight, drumstick weight and neck weight were affected significantly only by the interaction effects. Thus, improvement in drumstick will be best obtained by effect of interaction rather than considering individual effects of protein and energy. Adeyemi et al. (2008) further noted that dressed weight is more important to poultry meat consumers than the live weight because feathers add more to live weight and dressed weight represents the absolute value of saleable meat. The result of this study showed that improvement in live weight could be obtained best by interaction effect of $2700 \mathrm{kcal} / \mathrm{kg} \times 15 \% \mathrm{CP}$ or 2700 $\mathrm{kcal} / \mathrm{kg} \times 17 \% \mathrm{CP}$ since the individual effects of varying protein and energy levels did not produce significant effect.

\section{Conclusion}

The results of this study suggested that 
higher carcass performance could be achieved with Guinea fowl by feeding diet containing $15 \% \mathrm{CP}$ and $2700 \mathrm{kcal} / \mathrm{kg} \mathrm{ME}$.

\section{References}

Adeyemi, O. A., Ervubetine, D., Oguntona, T., Dipeolu, M. and Agunbiade, J. A. 2008. Feeding broiler chicken with diets containing whole cassava root meal fermented with rumen filtrate. Archivos de Zootecnia 57 (218): 247-258.

Agunbiade, J. A., Adepoju, O. A., Adeyemi, O. A. and Lawal. O. A. 2002. The role of whole cassava meal and leaf meal in broilers diet. Trop. Anim. Sci. 5 (1): $161-173$.

Ajala, M. K., Nwagu, B. I. and Osuhor, C. U. 1997. Socio-economics of freerage guinea fowl production among agro pastoral Fulani women in Giwa LGA of Kaduna State Nigeria. Inter. J. Trop. Agric.

Ayorinde, K. L. and Ayeni, J. S. O. 1983. Comparison varieties of indigenous guinea fowl (Numida meleagris) in Nigeria Kainji Lake Research Institute. New Bussa. Nigeria, pp: 120- 181.

Ayorinde, K L, Ayeni, J.S.O. and Oluyemi, J.A. 1988. Laying characteristics and reproductive performance of four indigenous helmeted guinea fowl varieties (Numida meleagrisgaleata Pallas).

Duncan, D. B. 1995. Multiple Range and Multiple F-Test. Biometrics. 11: 142.

Magaga, S. L. and Hanle, K. S. 1998. The domestication of guinea fowl: a case of Morogro Municipal, Tanzania, Nature fauna (Ghana) $14: 14-28$.
Micro livestock 1991. Little known small animals wity Promising economics Future, Board on Science and technology for International development, Washington, DC: National Academy Press, Washington, USA, pp 115-125.

Nahashon, S. N., Adefope, A. Amenyenu, A. and Wright, D. 2005. Effect of varying metabolisable energy and crude protein concentration on growth performance and characteristics of French guinea broilers Poults. Sc. 84:337-344.

Nahashon, S. N., Adefope, N., Amenyenu, A. and Wright, $D$. 2006 . Effect of dietary metabolizable energy and crude protein concentrations in diets of pearl gray guinea fowl pullets. 1 Growth performance Poult. Sci., 87: 1847-1854.

Nahashon, S. N., Adefope, N. A., Amenyenu, A. and Wright, D. 2007 . Effect of varying concentrations of dietary crude protein and metabolizable energy on laying performance of pearl; grey Guinea hens. Poult. Sc. Assoc. 86:1793-1799.

Nsoso, S. J. Seabo, G. M., Kgosiemang, J., Molathegi, S. G., Mokobela, M., Chabo, R. G. and Mine, $O$. M. 2003. Performance of progeny of wild and domesticated Guinea fowl (Numidameleagris) in Southern Botswana. South Africa. Anim. Sci. 4:46-51. http://www.Sasas.co. zalcientific /nsosoB.pdf.

Veicman, L. N. 1970. Guinea fowls. MosowRosselKhozizdal, 88pp.

Received: $25^{\text {th }}$ August, 2016 Accepted: 12 $2^{\text {th }}$ March, 2017 